\title{
Dějiny socialistického školství: terra inkognita historicko-pedagogického výzkumu? K problematice zdrojů poznání minulosti ${ }^{1}$
}

\author{
Jiří Zounek, Michal Šimáně, Dana Knotová \\ Masarykova univerzita, Filozofická fakulta, Ústav pedagogických věd
}

Redakci zasláno 28. 12. 2015 / upravená verze obdržena 27. 3. 2015 /

k uveřejnění přijato 30. 3. 2015

\begin{abstract}
Abstrakt: Př́spěvek se zaměřuje na problematiku zdrojů poznání minulosti při studiu dějin socialistického školství v Československu. Autoři si položili otázku, jaké zdroje má historik pedagogiky $\mathrm{k}$ dispozici, pokud se rozhodne zkoumat soudobé dějiny školství. Tuto otázku se přitom snaží sledovat zejména v souvislosti se základním školstvím v bývalém Jihomoravském kraji v letech 1969-1989. V první části textu autoři představují své schéma dělení zdrojů. $V$ následujících částech jednotlivé typy zdrojů (historické prameny, odborné publikace, pomocné zdroje a literatura) detailně rozebírají a doplňují konkrétními příklady. Příspěvek upozorňuje, že zdrojů k poznání dějin socialistického školství je poměrně velké množství. Bohužel doposud známé a dostupné zdroje pokrývají pouze některé části života škol či aktérů školního života. Zejména nezpracované archivní fondy představují poměrně zásadní limitující faktor v rozvoji historicko-pedagogického bádání. Na druhou stranu existuje celá řada odborné literatury a výsledky výzkumů z jiných oblastí historiografie, které mohou přispět k poznání soudobých dějin školství jak na národní, tak na regionální úrovni. To znamená, že historicko-pedagogický výzkum může stavět na poznatcích jiných oborů.
\end{abstract}

Klíčová slova: socialistické školství, historické prameny, odborné publikace, pomocné zdroje, archivní fondy

Historik je nadšeným otrokem pramenů, prameny jsou jeho milovaným a nenáviděným božstvem. Vždy s nimi zápasí, někdy třeba proto, že jich má v archivech celé vagóny a nikdy jich nebude moci přečíst ani malý zlomek procenta, a někdy ... že jich má až zoufale málo. (Třeštík, 1997, s. 7)

$1 \quad$ Studie je jedním z výstupů výzkumného projektu Každodenní život základní školy v období normalizace pohledem učitelů. Využití orální historie při studiu soudobých dějin školství, který je podporován GAČR (č. 14-05926S). Autoři děkují za podporu. 
Dějiny školství na našem území ve 20. století představují příběh rozdělený do několika kapitol. Jednu z nejdelších tvoří kapitola období socialistického školství ${ }^{2}$, ve které tato oblast prošla velmi složitým obdobím, stejně jako celá naše společnost. S pádem komunistického režimu se otevřela cesta nejenom k demokratickému a svobodnému vývoji v naší zemi, ale otevřela se možnost nezaujatě zkoumat období před rokem 1989. Jak uvádí ve své knize o perestrojce historik Michal Pullmann (2011), je potřebné zbavit se předsudků vůči normalizaci, potažmo vůči celému období komunismu, a přestat toto období démonizovat.

V podobném duchu se vyjádřil i Průcha (2011), když píše, že by se mělo ke studiu socialistického školství přistupovat jako ke každému jinému tématu nebo jiné etapě vývoje. Dějiny pedagogiky jako jedna ze základních disciplín pedagogiky prošla po roce 1989 poněkud paradoxním vývojem. Přestože ve vědě padly veškeré ideologické bariéry, výzkum i publikační činnost $v$ dějinách pedagogiky a školství v poslední dekádě 20. století stagnovaly (ve srovnání s léty před rokem 1989). Tento stav ukazuje studie Nejedlé (2000), která analyzovala kvantitativně i kvalitativně historická témata na stránkách odborného časopisu Pedagogika od jeho založení v roce 1950 do roku 2000. Podle autorčiny analýzy nebyly napřr v tomto časopisu v porevoluční době publikovány žádné výsledky empirického výzkumu socialistické školy, tj. konkrétně vývoje a proměn základních nebo středních škol ${ }^{3}$. Podobně je tomu v tomto období i u některých dalších odborných českých časopisů (viz např. Zounek \& Jedlička, 2005).

Zdá se tedy, že pořád platí slova jednoho z nejvýznamnějších českých historiků pedagogiky minulého století profesora Cacha (1991), který krátce po sametové revoluci píše o nechuti zabývat se kritickou analýzou vývoje naší školské soustavy po roce 1945. Průcha (2009b) v Pedagogické encyklopedii pak tento stav potvrzuje takřka o dvacet let později, když konstatuje, že dosud neexistuje vědecké zhodnocení etapy socialistického školství. Podíváme-li se ale do zahraničí, tak např. v sousedním Německu začali zkoumat socialistické

\footnotetext{
Používáme zde ve shodě s Průchou (2009a) termín socialistické školství jako časové vymezení (1948-1989), nikoliv jako kvalitativní označení.

3 Na počátku 90. let minulého století byly publikovány dvě zajímavé studie, které ale nejsou založeny na historickém výzkumu. Jde spíše o zamyšlení či svého druhu přehledové studie. Čermáková (1991) se věnuje zejména vzniku a rysům totalitního školství. Studie Cacha (1991) představuje nástin několika důležitých témat týkajících se socialistické pedagogiky a školství.
} 
školství již v 90. letech minulého století (viz např. Gruner \& Kluchert, 2001; Köhler, 2001; Pehnke, 2008; Tenorth, Kudella, \& Paetz, 1996).

Diskuzi na téma historického výzkumu soudobých dějin ${ }^{4} \mathrm{v}$ pedagogice u nás oživil Svatoš (2010) a Mareš (2010), který píše, že je čas věnovat se nedávné minulosti. „Časově by mělo jít o všechna důležitá období pedagogiky a školství, zejména bude třeba se věnovat normalizačním létům..." (Mareš, 2010, s. 101). 0 socialistické škole a zejména pedagogice se pak v návaznosti na citované autory diskutovalo i na stránkách Pedagogické orientace (Janiš, 2014; Maňák, 2013).

Zejména diskuze v časopise Pedagogika byla motivací pro náš výzkumný projekt, který si klade za cíl prozkoumat a popsat každodenní život základní školy v období normalizace. Výzkum je založen primárně na metodě orální historie, jejímž prostřednictvím získáme data o každodenním životě školy, ale také o životě a práci klíčových aktérů školního vzdělávání - učitelů. Abychom prozkoumali dané téma co nejdůkladněji a přitom zachytili širší historický rámec, využíváme v našem výzkumu také tradiční historické metody a zdroje (např̀ přímá a nepřímá metoda, studium archívních pramenů) ${ }^{5}$. Touto výzkumnou strategií jsme se nutně dostali k tématu zdrojů poznání, které je značně komplikované a místy nepřehledné, ale musí být v rámci výzkumu tohoto typu řešeno. $V$ dějinách pedagogiky u nás navíc doposud neexistuje žádná studie, která by tematizovala problematiku zdrojů poznání k soudobým dějinám školství a otevřela tak metodologickou (nejenom obsahovou či tematickou) diskuzi o výzkumu tohoto tématu.

Naší studií bychom chtěli zahájit takovou diskuzi a současně také navázat dílčím způsobem na výše uvedenou diskuzi v pedagogických časopisech. Budeme se tedy věnovat problematice zdrojů poznání minulosti, přičemž se orientujeme primárně na vývoj základního školství v období 1969-1989 na území bývalého Jihomoravského kraje (Zákon o územním členění státu č. 36/1960 Sb., 1960). Nicméně v mnoha ohledech budeme mapovat dějiny na území celého bývalého Československa a také v delším časovém rozmezí než posledních dvacet let před sametovou revolucí. V rámci této studie si

Neexistuje jednoznačné vymezení termínu soudobé dějiny, ale můžeme je ve shodě s mnoha autory vymezit jako dějiny, jejichž pamětníci či svědci stále žijí. Jde tedy o období posledních zhruba 70-80 let (podrobněji např. Pešek, 2013; případně také Vaněk \& Krátká, 2014).

5 Tímto postupem se snažíme vyvážit potenciální slabiny metody orální historie, ale také do jisté míry triangulovat data. 
klademe otázku, jaké zdroje má historik ${ }^{6}$ pedagogiky k dispozici při výzkumu soudobých dějin českého základního školství. ${ }^{7}$

Jde o klíčovou otázku historického výzkumu, protože dostupnost zdrojů k výzkumu určuje vůbec možnost zkoumat určité téma. Jinými slovy, nejsou-li dostupné zdroje či prameny $\mathrm{k}$ danému tématu (případně vůbec neexistují nebo byly zničeny), tak sebezajímavější téma nelze empiricky zkoumat. Nejde tedy pouze např́íklad o „nechut" na straně historiků zkoumat dané téma (at' už má ona nechut' jakékoliv důvody), ale také o realizovatelnost takového výzkumu. Na složitost výzkumu soudobých dějin upozornil již v roce 1983 Le Goff, když napsal, že historikové nemohou využívat archivů (protože nemají přístup $\mathrm{k}$ soudobým archiváliím) a při neexistenci dalších zdrojů se budou muset navrátit k psaní politické, vojenské a diplomatické historie - tedy beznadějně zastaralému stylu vypravování o minulosti, nebo k využití kvantitativních forem či využívat vágních konceptů jako je „veřejné mínění" nebo jiných forem subjektivismu. $V$ dnešní době vnímáme jeho myšlenku spíše jako důležité upozornění, že výzkum soudobých dějin nemusí být tak jednoduchý, přinejmenším co se zdrojů k poznání minulosti týká.

Na první pohled se totiž může zdát, že s dostupností zdrojů k tématu socialistického školství (potažmo dějin školství posledních zhruba sedmdesáti let) nemůže být žádný problém, protože nejde o nijak staré či „historické“ materiály. Nebyly tedy tak dlouho vystaveny působení „zubu času“ a navíc nebylo tolik příležitostí tyto materiály zničit (např. přírodní katastrofy, záměrné ničení během „revolučních“ let apod.). Jak ale uvádíme dále v našem textu, situace je poměrně složitá a výzkum soudobých dějin může být opravdu poměrně komplikovaný. Historik se tak může dostat do velmi složitých situací, v některých případech může jít dokonce o rozhodnutí nepokračovat ve výzkumu či zásadně změnit téma výzkumu. $V$ dějinách pedagogiky tedy nevstupujeme jen na tenký led, ale i na led, jehož kvalitu, rozsah či objem mnohdy vůbec neznáme.

6 V naší studii píšeme o historikovi pouze v mužském rodě, to ovšem neznamená, že ignorujeme ženy - historičky. Naopak si jejich práce velmi vážíme. Mužský rod používáme zejména $\mathrm{z}$ důvodu zjednodušení textu.

7 V naší studii se zaměřujeme především na období 1969-1989, a to nejenom s ohledem na téma našeho výzkumu. Takové zúžení tématu je nezbytné, abychom mohli alespoň $\mathrm{v}$ přehledu zachytit širokou škálu zdrojů, z nichž navíc mnohé pokrývají daleko delší historické období než dvacetiletí tzv. normalizace. Současně není reálně možné na ploše jedné studie zachytit všechny zdroje k tématu. Téma jsme zúžili i z důvodu zachování čtivosti a přehlednosti textu. Další zdroje pak mohou čtenáři nalézt v citované literatuře. 


\section{Zdroje poznání v historickém výzkumu}

Shromáždění všech dostupných zdrojů poznání minulosti (k danému tématu či výzkumu), zejména pak pramenů, jejich studium a intepretace je alfou a omegou valné většiny historicky orientovaných výzkumů. V odborné literatuře je proto věnován poměrně velký prostor problematice pramenů (viz např. Bartoš, 1977; Bernheim, 1931; Hroch, 1985; McCulloch \& Richardson, 2000; Skládaný, 2009; Vaculík \& Čapka, 2011; Zwettler, Vaculík, \& Čapka, 1996).

V nadpisu této části studie jsme záměrně nepoužili termín pramen. Důvodem je to, že mezi zdrojem a pramenem vnímáme rozdíl, který je důležitý pro pojetí „informační“ základny v historickém výzkumu. Zdroj poznání minulosti chápeme šířeji než pramen, a to jako veškeré dostupné a využitelné materiály, informace a poznatky (ve fyzické i digitální podobě), které je možné využít při zkoumání minulosti. Ke zdrojům poznání v historicko-pedagogickém výzkumu tak řadíme vedle pramenů a odborné literatury také metodologickou literaturu, naučné i jazykové slovníky, encyklopedie, archivní pomůcky, učebnice dějin pedagogiky, ale také odborné konzultace, diskuze s odborníky na konferencích, diskuzní fóra zaměřená na problematiku dějin na internetu apod. (viz např. Aldrich, 2003). Vymezení zdrojů poznání minulosti je poměrně široké, ale nikoliv bezbřehé, protože vždy musí jít o zdroje související $\mathrm{s}$ minulostí či se k poznání minulosti vztahující. $V$ našem případě s dějinami pedagogiky a školství. Je zřejmé, že zde prakticky vždy existuje nebezpečí „utopení se" v moři zdrojů. To je ovšem vyváženo menším rizikem pominutí zdánlivě nesouvisejícího, ale pro zkoumané téma důležitého zdroje. V našem širokém vymezení jde zejména o otevřenost $\mathrm{k}$ mnohdy zcela odlišným typům zdrojů a současně o odbornou citlivost v jejich výběru.

Jako stále důležitější součást zdrojů poznání vnímáme různorodé zdroje, které jsou dostupné v digitální podobě. $V$ některých př́ípadech jde o digitalizované originální historické prameny, v jiných případech může jít o různé digitalizované archivní pomůcky či publikované odborné studie dostupné v elektronických databázích knihoven. Digitalizací pramenů, ale i dalších typů zdrojů se mohou měnit mnohé aspekty práce historika. Může jít o rychlejší vyhledání informace v digitalizovaném prameni, nebo v odborné literatuře či encyklopediích dostupných online (podrobněji např. Weller, 2013).

Historický pramen vnímáme jako zásadní zdroj poznání minulosti, protože jde o zdroj blízký historickému ději, nebo jde př́mo o součást či výsledek takového děje. „Pramen je pro historika materiálem, z něhož čerpá poznatky o minulosti. Pramen je součást (mnohdy také výsledek) historického procesu 
(dění) a je danému jevu v minulosti blízký časově i prostorově" (Zounek \& Šimáně, 2014). Ve shodě se současným pojetím pramene v moderní historiografii (viz např. Skládaný, 2009; Vaculík \& Čapka, 2011) vnímáme pramen ovšem nejen jako statický materiál, z něhož je možné získat poznatky o minulosti, ale „jako soubor vlastností tohoto materiálu, který tvoří určitou informační strukturu konstituovanou na základě otázek kladených historikem“ (Skládaný, 2009, s. 235). To je velmi důležitá proměna v chápání pramene, protože již není kladen důraz pouze na vlastnosti či kvalitu historického materiálu, ale také na úroveň historického poznání, metodologickou výbavu historika i na použité metody. Na jedné straně je tu tedy pramen, který musí být nalezen a musí být „využitelný“ pro poznání minulosti. Jinými slovy musí nést/obsahovat určitou informaci. Na druhé straně je tu historik, který má $\mathrm{k}$ dispozici teoretickou i metodologickou výbavu $\mathrm{k}$ tomu, aby vhodně zvolenými otázkami a následně zvolenými postupy (metodami) získal relevantní informace z pramenů různé povahy, a to vždy s ohledem na výzkumnou otázku (jinými slovy „vytěžit“ pramen). Zdaleka nemusí jít pouze o písemné prameny, ale může jít o prameny vizuální, orální nebo trojrozměrné. Naše pojetí a členění zdrojů poznání minulosti ukazuje následující schéma (obr. 1).

V našem pojetí nepracujeme s termínem sekundární pramen, který lze podle Jůvy (2009, s. 674) definovat jako „všechny vědecké texty, jež zprostředkovávají poznání obsahu primárního pramene.... Pro tento typ zdrojů používáme termín odborná literatura/studie. Vycházíme přitom $\mathrm{z}$ našeho vymezení historického pramene, které vnímá pramen jako součást či výsledek historického procesu. U odborné literatury či studií vstupuje do hry rovněž osobnost autora (jeho kvalifikace, vztah k popisované události, záměr k sepsání publikace atd.), navíc literatura pracuje s primárními zdroji, které jsou autorem vybrané a interpretované. $\mathrm{Z}$ těchto důvodů se nám nejeví termín (sekundární) pramen adekvátní. Klasifikace slouží především jako pomůcka $\mathrm{k}$ tomu, abychom mohli znázornit celou širokou paletu zdrojů a mohli tak ukázat rozdíly mezi jednotlivými typy zdrojů. ${ }^{8}$

8 V naší snaze o komplexní přehled o zdrojích poznatků k danému tématu se neubráníme jistým zjednodušením. U jednotlivých typů zdrojů nemůžeme v rámci jedné studie podat vyčerpávající přehled př́ikladů či ukázek daného typu zdroje či pramene. Při výběru př́́kladů jsme se řídili zejména relevantností konkrétního zdroje vzhledem k typu zdroje, ale také jeho dostupností a aktuálností obsažených informací. Přesto se neubráníme subjektivitě výběru, kterou jsme se ale snažili kontrolovat diskuzemi v rámci autorského týmu či nezávislým vyhledáváním zdrojů všemi autory studie. Náš postup ale do jisté míry podporuje komplexnost náhledu, protože v citovaných zdrojích lze dohledat další zdroje a tím podstatně rozšírít i prohloubit poznání tématu. Neměl by tak zůstat opomenut žádný významný zdroj poznání. 


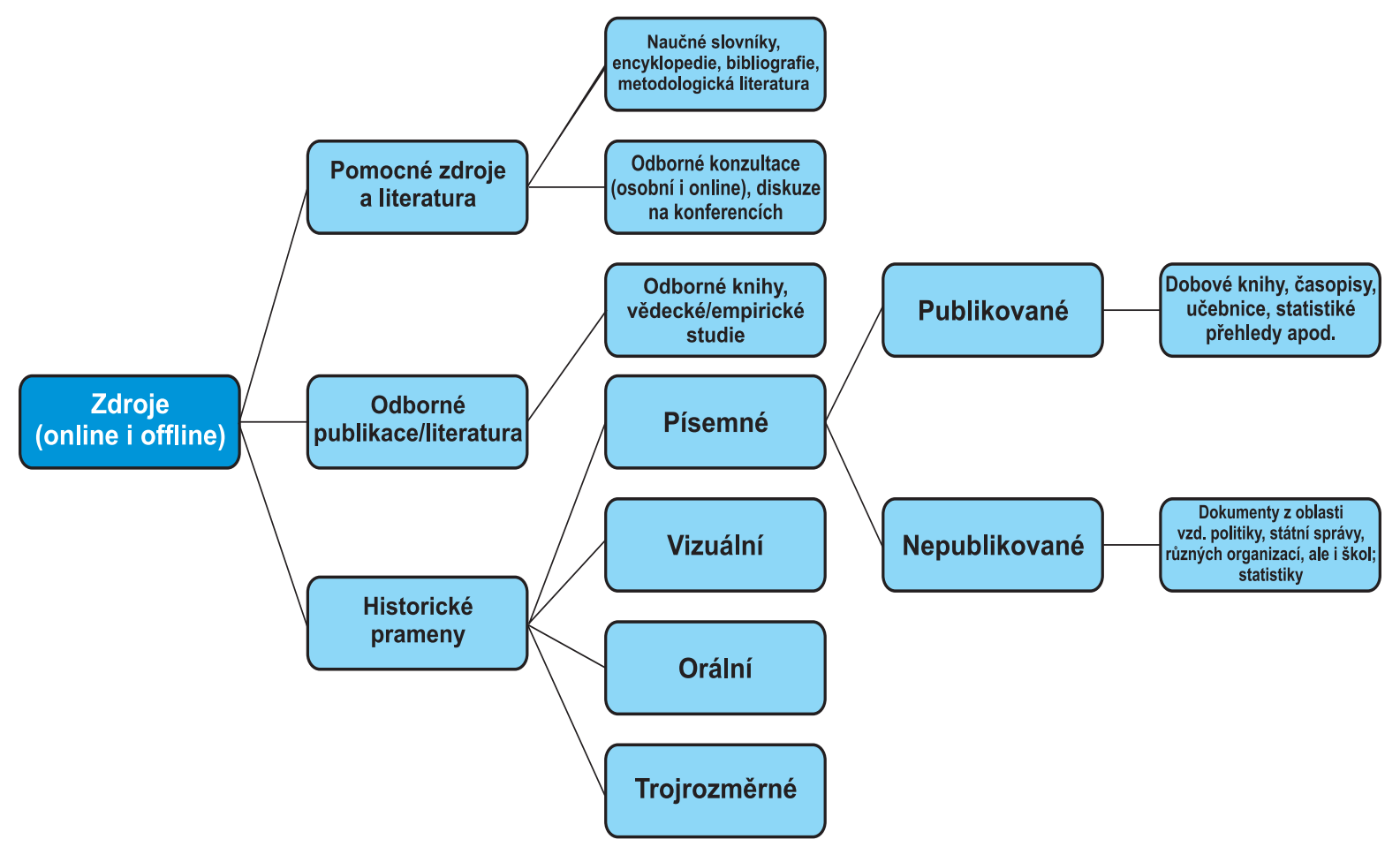

Obrázek 1. Schéma rozdělení zdrojů.

\subsection{Pomocné zdroje a literatura}

Tento typ zdrojů provází historika $\mathrm{v}$ průběhu celého výzkumu. V základní orientaci v terminologii dějin pedagogiky může pomoci Pedagogický slovník (Průcha, Walterová, \& Mareš, 2013). Důležitým pomocným zdrojem je bezesporu Pedagogická encyklopedie (Průcha, 2009a), která obsahuje heslo o dějinách školství na našem území v letech 1948-1989, ale také metodologicky orientované heslo historická pedagogika. Za pozornost stojí rovněž heslo o dějinách vzdělanosti (Svatoš, 2009). U každého hesla je doplněna použitá literatura, což umožňuje dále prohlubovat poznání určitého tématu.

$\mathrm{K}$ metodologii historického výzkumu $\mathrm{v}$ pedagogice se stručně vyjadřuje rovněž Hendl ve své práci o kvalitativním výzkumu (Hendl, 2005). Velmi zajímavé a př́nosné poznámky $\mathrm{k}$ historickému výzkumu a problematice pramenů (jejich vymezení, upozornění na možnosti zkreslení apod.) pak obsahují i starší publikace Traverse (1969) a Kerlingera (1972). Zajímavým př́spěvkem k metodologii historického výzkumu je kniha Konopáska (1999) Otevřená minulost: autobiografická sociologie státního socialismu. Publikace 
se věnuje životopisným vyprávěním, jež byla využita v rámci unikátního výzkumu, $\mathrm{v}$ jehož rámci se skupina sociologů zabývala vlastními životopisnými vyprávěními. Kniha přináší nejenom celou řadu metodologických poznatků, ale také poznatky o životě v socialistické společnosti, čímž může být důležitým zdrojem i pro dějiny pedagogiky.

Ze zahraničních zdrojů lze uvést práce Research methods in education (Cohen, Manion, \& Morrison, 2007), kde je samostatná kapitola věnovaná historickému výzkumu. Zajímavou metodologickou příručku představuje Historical research in educational settings (McCulloch \& Richardson, 2000), která však pracuje s poněkud netypickým dělením pramenů pro české prostředí a argumentace i př́klady jsou čerpány převážně z prostředí Velké Británie. Její předností je orientace na otázky historicko-pedagogického výzkumu, nikoliv pouze na metodologii obecné historiografie.

V oblasti obecných dějin existuje velké množství publikací, které se zabývají přímo dějinami let 1969-1989, nebo mapují období komunismu či poválečné dějiny. Př́kladem může být Slovník českých dějin (Vykoupil, 2000), kde autor formou věcných hesel vysvětluje normalizaci, Pražské jaro 1968, únorové události roku 1948 nebo odhaluje vznik pojmu železná opona. Méně známou, ale velmi rozsáhlou online publikací o dějinách komunismu u nás (včetně problematiky školství) je Slovníková prríručka k československým dějinám 1948-19899. Na bezmála 900 stranách jsou popsány ve formě věcných hesel všechny podstatné aspekty života v socialistické společnosti (politika, sociální otázky, kultura, hospodářský vývoj apod.). V tištěné i online podobě je dostupná kniha F. Čapky Dějiny zemí Koruny české v datech (2006). Př́kladem bibliografie může být práce Břeňové (datum vydání neuvedeno), která zpracovala patnáct ročníků odborného časopisu Soudobé dějiny. Z metodologické literatury lze uvést prakticky všechny publikace zabývající se v českém prostředí „úvodem do studia dějepisu“. Některé z nich jsou poplatné době svého vzniku (Bartoš, 1977; Hroch, 1985), ale ve všech lze najít důležité informace a poznatky k metodologii historického výzkumu, práci s prameny, k metodám historického výzkumu, postupu práce historika, kritice pramenů. Novější práce pak reflektují i aktuální trendy v historických vědách (viz např. Skládaný, 2009; Úvod..., 2014; Vaculík \& Čapka, 2011; Zounek \& Šimáně, 2014).

$\overline{9}$ Autorem hesel o školství a pedagogice je prof. J. Průcha. 
V poslední době vyšlo několik metodologických knih, které se věnují komplexně teorii i praktickým otázkám empirického výzkumu založeného na metodě orální historie (viz např. Vaněk, 2004; Vaněk, Mücke, \& Pelikánová, 2007; Vaněk \& Mücke, 2011; Vaněk, 2013). Zejména kniha Třetí strana trojúhelníku: teorie a praxe orální historie (Vaněk \& Mücke, 2011) představuje ucelenou metodologickou publikaci obsahující nejen praktické otázky výzkumu (příprava a vedení rozhovoru, jeho zpracování, etické i legislativní otázky výzkumu apod.), ale také teoretické základy metody orální historie (vymezení metody, studium paměti a orální historie, možnosti a limity metody ad.). Důležitou součástí je rozsáhlý a fundovaný popis vývoje orální historie ve světě.

Neměli bychom zapomínat, že důležitým zdrojem poznání jsou konzultace s odborníky. Příkladem může být komunikace s pracovníky archívu, kteří mohou výrazně pomoci s orientací v nezpracovaných archívních materiálech, jak ukazuje citace $\mathrm{z}$ emailu adresovaného J. Zounkovi ${ }^{10}$ :

... v našem archivu se nachází fond B 338 Jihomoravský krajský národní výbor Brno (1960-1990). Součástí Jm KNV byl odbor školství a kultury, jehož spisy ve třech manipulacích (1. z let 1958-1976, 2. z let 1976-1987 a 3. z let 1987-1990) jsou u nás uloženy. ... Problém je ale v tom, že fond B 338 není zpracovaný, a tudíž je pro badatele nepř́ístupný. Je možné si zažádat ... o možnost nahlížet do nezpracovaného materiálu...

$\mathrm{V}$ rámci této tematiky nesmíme zapomenout na jeden $\mathrm{z}$ velmi důležitých zdrojů informací, kterými jsou odborné konference. Na konferencích nejde jen o prezentace a obhájení výsledků výzkumu a jeho metodologie, ale také o zodpovězení př́ípadných otázek, z nichž některé mohou posunout uvažování do oblastí, o nichž autor/autoři dříve neuvažovali. Dủležitou součástí konferencí jsou neformální diskuze s kolegy, at' už jde o národní, či mezinárodní komunitu. K významným konferencím v ČR patří konference České asociace pedagogického výzkumu ${ }^{11}$ nebo konference České pedagogické společnosti ${ }^{12}$. Na mezinárodní úrovni lze uvést Evropskou konferenci pedagogického výzku$m u^{13}$. Z oblasti historického výzkumu je možné zmínit např. Evropskou konferenci dějin sociálních věd ${ }^{14}$, kde je tematika školství zmiňována v rámci sekcí

\footnotetext{
Email je součástí pracovní elektronické komunikace J. Zounka.

11 Česká asociace pedagogického výzkumu - více informací o konferenci viz http://www.capv.cz.

12 Česká pedagogická společnost - více viz http://www.cpds.cz.

13 European conference on educational research - více viz http://www.eera-ecer.de.

14 The European social science history conference - více viz https://esshc.socialhistory.org.
} 
o hospodářských dějinách, ale i v sekci věnované orální historii. Za tradiční již můžeme považovat také konferenci České asociace orální historie ${ }^{15}$, která se věnuje metodologickým otázkám, ale přináší zejména výsledky současných výzkumů.

\subsection{Odborná literatura a studie}

Do této kategorie řadíme veškeré vědecké (odborné) publikace, studie či jiné formy sdělení v tištěné i v digitální podobě. Jde přitom o texty, které přinášejí nové poznatky získané na základě teoretického nebo empirického výzkumu (případně jde o odborné přehledové studie) a jsou určeny vědeckým pracovníkům, př́ípadně odborníkům vzdělaným $\mathrm{v}$ dané oblasti. Takové texty se řídí určitými pravidly (byt' ne vždy explicitně řečenými) a obsahují náležitosti vědeckého textu (poznámkový aparát, dodržování citační normy apod.). Podrobněji o této problematice viz např. Čmejrková, Světlá a Daneš (1999), Hendl (2005), Mareš (2013).

V pedagogice vyšlo v posledním desetiletí několik přehledových studií mapujících dějiny školství na našem území. Studie Walterové ${ }^{16}$ nazvaná Vývoj české školy v knize Úloha školy v rozvoji vzdělanosti (Walterová, 2004) představuje zajímavý přístup $\mathrm{k}$ vysvětlení dějin české, zejména základní, školy. Autorka v textu vystihuje hlavní časové mezníky, legislativní rovinu vývoje, využívá přitom jako zdroje zejména dostupnou odbornou literaturu či dobové odborné časopisy. Popisuje především principy, podstatu či trendy, které převládaly ve školství či školské politice v dané etapě vývoje. Cenné je zde vystižení právě obecných charakteristik daného historického období. Podobně postupuje Rýdl (2006), který se ovšem zaměřuje zejména na vývoj a proměny správy a řízení škol. Rovněž v této studii je zajímavé vystižení základních charakteristik daného historického období. Studie Vorlička (2004) mapuje období socialistického školství především na základě studia oficiálních pokynů a legislativních dokumentů, ale využívá i dobové autory. V závěru pak autor shrnuje základní tendence v socialistickém školství. Vedle těchto tendencí seznamuje tato studie s obsahem mnohých legislativních norem. ${ }^{17}$ Za zmínku zde stojí kniha Cesta ke svobodné škole: kapitoly ze srov-

15 Více viz www.oralhistory.cz.

16 Prof. Walterová je autorkou historického nástinu pouze do roku 1989, autorem následující kapitoly je prof. Kotásek.

17 Žádná z těchto studií není založena na vlastním historickém výzkumu, nebo zde metodologie není explicitně uvedena. 
návací pedagogiky (Václavík, 1997), v níž je jedna stručná kapitola věnovaná socialistické pedagogice. Jde spíše o úvahu, zajímavé jsou zde odkazy a citace některých dokumentů, jako např. tzv. učitelský slib.

Jednou z nejnovějších knih, která se věnuje dějinám škol a životu i práci učitelů zhruba od 60. let minulého století až po současnost, je práce D. Moree (2013) Učitelé na vlnách transformace: kultura školy před rokem 1989 a po něm. Autorka popisuje a vysvětluje život a proměny dvou škol a učitelů $\mathrm{v}$ jednom městě, přičemž využívá kvalitativní metodologii, konkrétně narativní výzkum (hlavní metodou sběru dat byly rozhovory, dále pak v menší míře využila analýzu dokumentů). Díky použité metodologii pronikla do kultury obou škol, do vnitřního života škol i do životů učitelů, jejich vnímání profese učitele před rokem 1989 a po něm. ${ }^{18}$

Podíváme-li se na odbornou produkci v oblasti obecných dějin, př́ípadně konkrétněji do publikací z oboru politických, hospodářských, sociálních dějin či soudobých dějin, tak se před námi otevře obrovské množství velmi různorodých odborných zdrojů. Nesmíme zapomínat i na další obory, které se zabývají v rámci svých výzkumných aktivit studiem minulosti. Příkladem může být sociologie nebo politologie ${ }^{19}$, př́padně geografie a kartografie (Kučerová, 2012). Není zde proto možné zmínit všechny zdroje, ale ukážeme vybrané zdroje v poněkud pro historiografii netradičním pohledu. Odborné publikace rozdělujeme na ty, které využívají primárně kvantitativní data či prameny kvantitativní povahy. Věnují se především makrohistorii či jinak řečeno událostním/globálním dějinám (Medick, 2001). Druhou skupinou jsou ty publikace, které pracují s prameny nekvantitativní povahy a používají převážně metody kvalitativního výzkumu (zkoumají zejména mikrohistorii, ale i makrohistorii ${ }^{20}$ ).

18 Tato studie jako jediná obsahuje explicitně popsanou a vysvětlenou metodologii výzkumu včetně teoretického rámce, což je $\mathrm{v}$ historicko-pedagogickém výzkumu zatím poměrně ojedinělá věc.

$19 \mathrm{Z}$ politologie je $\mathrm{k}$ tématu socialistického školství zajímavý např titul Teorie a praxe nedemokratických režimů (Balík \& Kubát, 2012). Publikace se netýká školství, ale vysvětluje, co to je totalitní a autoritářský režim a mnohá další témata, která jsou důležitá pro pochopení širšího kontextu, $v$ němž školy $v$ době socialismu fungovaly.

20 Například v př́ípadě školské politiky se zkoumají kvalitativními metodami (obsahová analýza dokumentů) školsko-politické dokumenty, které ovlivňovaly zásadně směřování celé vzdělávací soustavy, tedy typicky makrohistorické téma. Slabina našeho rozdělení a současně nesnáz je $\mathrm{v}$ tom, že $\mathrm{v}$ historických publikacích nebývá tradičně uváděna metodologie výzkumu, proto je mnohdy velmi obtížné jasně rozpoznat výzkumné metody. 
Kvantitativní data využívají mnohé publikace k vysvětlení sociálního, hospodářského či kulturního vývoje. Př́́kladem velmi zajímavého zdroje k dějinám školství v období normalizace (či celému období socialistického školství) je dvousvazková monografie Hospodářské a sociální dějiny Československa 1918-1992 (V. Průcha, 2009). Druhý svazek této rozsáhlé publikace je věnován období po druhé světové válce. Dějiny školství (a vzdělanosti obyvatelstva) jsou jen jedním z mnoha témat, kterými jsou např. sociální politika či proměny sociální struktury společnosti, ale také procesy urbanizace, populační vývoj či změny ve způsobu života. Autoři mapují i rozdíly mezi českými zeměmi a Slovenskem, případně, jsou-li k dispozici data, tak srovnávají tehdejší Československo se zahraničím. Podobně studuje poválečné Československo ve svých publikacích Kalinová $(1998,2012)^{21}$, která využívá ve svých pracích takřka výhradně kvantitativní data. Dalším významným zdrojem pro dějiny školství pro období konce normalizace a zejména období transformace je Zpráva o vývoji české společnosti 1989-1998 (Matějů \& Večerník, 1998). Autoři mapují nejenom kvantitativní a institucionální změny školského systému, ale mapují i názory lidí na vzdělání ve vztahu k životnímu úspěchu a mnohé další otázky. Používají celou řadu kvantitativních zdrojů a výzkumů, a to nejenom českých, ale i mezinárodních. Ačkoliv se publikace zaměřuje zejména na první polovinu 90. let minulého století, najdeme zde celou řadu dat k roku 1989 či 1990. Lze tak studovat svého druhu „dědictví“ socialismu (nejenom) v oblasti školství. Všechny uvedené publikace jsou důležité pro dějiny školství i pro kontext, v němž se školství rozvíjelo. Významné jsou přitom nejenom výsledky analýz autorů uvedených publikací, ale také používané/citované zdroje či prameny, které mohou posloužit výzkumníkům v dějinách pedagogiky $\mathrm{k}$ detailnějšímu studiu. $\mathrm{V}$ těchto publikacích nelze ale vcelku pochopitelně očekávat detailní rozbory pedagogicko-didaktických otázek dobového školství.

Kvalitativně orientované (či tradičně orientované) odborné historické zdroje tvoří rovněž široký proud odborných publikací a studií, který není možné komplexně obsáhnout $\mathrm{v}$ rámci jedné studie. Ukážeme proto vybrané př́íklady, na nichž je možné dokumentovat šiřri zdrojů, které jsou v současnosti $\mathrm{k}$ dispozici.

21 Lenka Kalinová je rovněž autorkou některých kapitol ve zmiňované knize V. Průchy z roku 2009. 
Vzhledem k zaměření naší studie je nutné na prvním místě zmínit výzkumnou a publikační činnost Ústavu pro soudobé dějiny AV ČR ${ }^{22}$, který má výzkum tohoto období jako hlavní cíl i smysl své práce. Na tomto pracovišti je řešeno $\mathrm{v}$ době psaní této studie hned několik výzkumných projektů týkajících se období socialismu (např. Česká společnost v období tzv. normalizace a transformace: životopisná vyprávěni ${ }^{23}$, nebo Rezistence vůči komunistickému režimu v Československu 1948-1989. Její zdroje, projevy a ohlasy). Ústav vydává časopis Soudobé dějiny, který vychází již od roku 1993 a přináší nejnovější poznatky z výzkumů, ale i recenze knih a diskuze odborníků. Součástí Ústavu pro soudobé dějiny je např. Centrum orální historie, ale také Centrum pro studium menšin a další pracoviště. Pro studium dějin socialistického školství jsou důležité jak výsledky v oblasti výsledků výzkumů, tak metodologicky orientovaná témata či diskuze (např̀ v časopisu Soudobé dějiny, ale i na mnohých seminářích organizovaných tímto pracovištěm).

K poznání soudobých regionálních dějin přispívá například také kolektivní publikace Člověk na Moravě ve druhé polovině 20. století (Fasora et al., 2011). Autoři jednotlivých studií se snaží prostřednictvím životních příběhů jedinců ukázat život $\mathrm{v}$ širších kontextech dané doby. $\mathrm{V}$ publikaci jsou představeny např́klad osudy šlechtice, předsedy jednotného zemědělského družstva, univerzitního studenta, dělnice, ale i učitele (Zounek, 2011) a mnoha dalších. Kniha tak přináší velké množství poznatků ke každodennímu životu (převážně) v období socialismu. Zajímavé je i pojetí a zpracování jednotlivých studií.

K předním českým badatelům v oblasti soudobých dějin patří profesor Milan Otáhal, který je autorem celé řady knih o socialistickém Československu v době normalizace, přičemž se zabývá zejména tematikou opozice (viz např. Otáhal, 1994, 2002, 2011). Důležité poznatky přináší kniha Svědectví o duchovním útlaku 1969-1970: Dokumenty: „Normalizace“ v kultuře, umění, vědě, školství a masových sdělovacích prostředcích (Otáhal, Bolomský, \& Nosková, 1993).V publikaci je zveřejněno několik dokumentů, které vznikly na půdě ideologické komise Komunistické strany Československa, která měla na starosti sdělovací prostředky, kulturu, umění, školství. ${ }^{24}$ Kniha je

22 Přehled činnosti, publikační aktivity, řešené výzkumné projekty apod. lze najít na webových stránkách http://www.usd.cas.cz.

23 Z tohoto projektu jsou již publikovány dílčí výstupy, viz např. Vaněk (2013), Vaněk a Krátká (2014).

24 V knize a ve vybraných dokumentech je ovšem věnováno nejvíce prostoru vysokému školství. 
důležitá nejenom faktograficky, ale i metodologicky, protože ukazuje, kde jsou uloženy různé druhy pramenů, zejména dokumenty KSČ.

Dějiny vysokého školství popisuje ve své knize Vysokoškolský vzdělávací systém v letech tzv. normalizace Urbášek (2008). Také tato kniha poskytuje celou řadu metodologických poznámek, protože autor studoval mnoho pramenů $\mathrm{z}$ různých archívů, ale měl $\mathrm{k}$ dispozici i nepublikované výzkumné zprávy, paměti a vzpomínky. Kniha představuje zajímavý příspěvek k dějinám vysokého školství (potažmo vzdělanosti) v období normalizace, ale obsahuje i poznatky k formování socialistického vysokého školství po roce 1948.

0 reflexi české historické paměti na dobu komunismu se pokusila ve své knize Češi a jejich komunismus: pamět' a politická identita francouzská historička Françoise Mayer (2009). Autorka analyzovala různé typy diskurzů (oficiální, akademický aj.), které chápe jako různá vidění minulosti. Cílem knihy je prozkoumat „mechanismy vzniku kolektivní paměti na komunismus v české společnosti v 90. letech" (Mayer, 2009, s. 23). V našem prostředí jde o zatím ojedinělý pokus a př́istup k dějinám před rokem 1989.

V závěru této části je nutné zmínit ojedinělý př́istup $\mathrm{k}$ dějinám českého školství, který zvolila Kučerová ve své knize Proměny územní struktury základního školství v Česku (2012). Autorka se snaží popsat a vysvětlit hlavní procesy, které utvářely sít' základních škol u nás v posledních zhruba padesáti letech. Autorka studovala jak data pro celou republiku, tak detailněji zkoumala několik konkrétních lokalit, kde došlo k uzavření školy, aby tak lépe pochopila důsledky této události na život a fungování daných lokalit či společenství. Ve své knize tak kombinuje geografické či historicko-geografické, ale také pedagogické či sociologické přístupy ke zkoumání soudobých dějin našeho školství.

\subsection{Historické prameny}

Práce $s$ historickými prameny představuje jádro práce každého historika. Na tomto místě se budeme zaměřovat na samotné historické prameny, jejich uložení, reálnou dostupnost pro badatele a také naznačíme, jaké informace je možné v různých typech pramenů najít či alespoň očekávat. ${ }^{25}$

25 Kritika pramenů či metody práce historika s prameny již sahají nad rámec této studie, čímž rozhodně nechceme říci, že jde o méně významné fáze historického výzkumu. $K$ této problematice se stručně vyjadřujeme v publikaci Úvod do studia dějin pedagogiky a školství: kapitoly z metodologie historicko-pedagogického výzkumu (Zounek \& Šimáně, 2014). 


\section{Písemné prameny nepublikované}

Jednou ze zásadních otázek mnohých historicko-pedagogických výzkumů je dostupnost písemných pramenů, která může výrazně omezit i možnosti zkoumání soudobých dějin školství. Dostupnost ovlivňují zejména dva zásadní faktory. Jedním z nich je Zákon o archivnictví a spisové službě a o změně některých zákonů (č. 499/2004 Sb.), v němž se v paragrafu 37 (odst. 1) uvádí: „K nahlížení v archivech jsou přístupné jen archiválie starší třiceti let, není-li dále stanoveno jinak“. $V$ praxi to znamená, že se ve většině př́padů badatel dostane pouze k pramenům do roku 1985 (v době dokončování této studie).

Druhým faktorem ovlivňujícím dostupnost je zpracování archiválií či celých archívních fondů, které obsahují dokumenty ke školství. K výzkumu dějin školství v bývalém Jihomoravském kraji je významný Moravský zemský archiv (MZA) v Brně. ${ }^{26}$ Jak jsme již naznačili citací z emailu výše, v tomto archivu existuje fond B 338 Jihomoravský krajský národní výbor Brno, jehož součástí je odbor školství a kultury (1960-1990). Ten ovšem není zpracovaný, a tudíž není badatelům dostupný. ${ }^{27} \mathrm{~K}$ fondu existuje inventář, který naznačuje, že fond obsahuje velmi cenné informace k mnoha oblastem života škol, ale i nadřízených úřadů. Ve fondu ${ }^{28}$ se nacházejí např. Dlouhodobý program rozvoje školství do roku 1980, oběžníky odboru školství a kultury, komise pro rozmístění žáků 8 . tř́íd, kádrové materiály, komise elektronizace, pětileté plány ve školství, pedagogické věci, dislokace učitelů, řízení práce škol, pracovní plány a řády, přijímací řízení, odvolací řízení, inspekční protokoly, zprávy o stavu školství a mnohé další. Uvedené příklady typů uložených písemností přitom mají různý rozsah, a to od několika složek až po několik desítek kartonů. ${ }^{29}$

26 Na tomto místě chceme poděkovat paní ředitelce MZA PhDr. Kateřině Smutné a paní Mgr. Michaele Růžičkové, které nám umožnily prostudovat několik krabic z fondu B 338, díky čemuž máme základní představu o charakteru uložených dokumentů. Konkrétně šlo o: Zprávy o stavu školství 1979-1984 (3 balíky), Dlouhodobý program rozvoje školství do roku 1980 (1 pořadač), Plán práce ve školství (1971-1975) - 1 pořadač.

27 V MZA jsou uloženy rovněž fondy G 560 KSČ-KV Brno (1945-1960) a G 593 KSČ-Jmk Brno (1960-1989), které jsou dostupné, což znamená velkou výzvu nejen pro historický výzkum, ale také pro historicko-pedagogický výzkum.

28 Uvedené názvy jsou označení uložených (skupin) písemností dle inventáře fondu. Některé názvy byly zkráceny.

29 Jde o archívní kartony o tloušt'ce zhruba $10-12 \mathrm{~cm}$. Složkou je typicky myšlena běžná složka na max. desítky jednotlivých listů papíru. 
Další důležitou institucí s ohledem na téma naší studie je Archiv města Brna $(A M B), v$ němž je situace podobná, protože fond $B$ 1/3030 odbor školství a kultury je nezpracovaný a nepřístupný (bohužel k němu neexistuje ani inventář). ${ }^{30} \mathrm{Z}$ uvedených příkladů vyplývá, že nepublikované (archívní) materiály jsou v současné době prakticky nedostupné, a to i přes maximální vstř́ícnost pracovníků obou zmíněných archívů. Na základě našich výzkumných sond do zmíněných fondů lze říci, že obsahují obrovské množství historických materiálů, které mohou napomoci při výzkumu řízení socialistických škol, jejich fungování, tehdejší podoby plánování ve školství a vzdělávání. Potenciálně archiválie umožní blíže poznat také práci učitelů či jejich (další) vzdělávání, ale bude možné poznat do jisté míry i život a učení tehdejších žáků.

\section{Písemné publikované prameny}

Pramenná základna v oblasti nepublikovaných písemných „materiálů“ může být v mnoha ohledech velmi omezená (alespoň prozatím). Historik však má $\mathrm{k}$ dispozici ještě publikované písemné prameny, které mohou doplnit a někdy i do určité míry nahradit nedostupné nepublikované (archivní) prameny. Opět na příkladu pramenů k dějinám školství v Jihomoravském kraji v období normalizace ukážeme možné druhy pramenů. Dějiny školství v jednom kraji ovšem nelze separovat od dějin celého tehdejšího Československa, proto je nutné studovat i prameny obsahující informace o celé tehdejší ČSSR.

Základní údaje o populaci (dosaženém vzdělání/dokončené škole, navštěvované škole apod.) mohou poskytnout sčítání lidu (Československé sčítání lidu, 1970, 1980, 1991). Velmi cenným zdrojem je Historická statistická ročenka ČSSR z roku 1985, v níž najdeme data např. o základních školách od roku 1936 (mimo válečné roky) až do roku 1983. Jsou zde popsány počty škol, tříd, žáků i učitelů. Podobné údaje jsou ke školám pro mládež vyžadující zvláštní péči, ale uvedeny jsou údaje rovněž ke školním družinám a klubům. Analogicky jsou zpracována data o středních školách, gymnáziích (či středních všeobecně vzdělávacích školách), ale i vysokých školách. Vedle toho ročenka obsahuje informace k proměnám domácností a rodiny, vývoj mezd, sociálního zabezpečení či zdravotnictví.

Dějinami školství ve větším detailu se zabývá např. práce Základní školství v ČSSR a některé trendy jeho vývoje od roku 1921 (Jelínková \& Smolka,

30 Chceme poděkovat panu řediteli AMB PhDr. Liboru Blažkovi, paní Mgr. Kateřině Kalvodové paní Monice Kadlčíkové a paní Ludmile Dvořákové za spolupráci a odborné konzultace. 
1989), v níž můžeme najít souhrn dokumentů, vyhlášek, zákonů pro období 1948-1989, průměrný počet žáků na třídu v ČSSR a ČSR (v letech 1953-1989), celkový počet učitelů (včetně podílu žen), počty absolventů studia učitelství (1980-1989), feminizaci ve školství a mnohé další informace. Vedle toho publikace přináší např́íklad také informace o tzv. směnném vyučování. ${ }^{31}$ Autoři uvádějí vývoj počtu žáků ve druhé a dokonce třetí směně (údaje jsou rozděleny podle krajů). $V$ knize je ke směnnému vyučování uveden krátký komentář, z něhož nelze vyčíst nic podrobnějšího např́íklad o třetí směně. Ukazuje to však na fakt, že v některých oblastech (zejména na Slovensku) byl v určitých letech výrazný nedostatek škol, což bylo důvodem „směnování“. Jihomoravský kraj např́klad patřil ve školním roce 1969/1970 ke krajům s nejvyšším podílem směnujících žáků na tehdejší základní devítileté škole v ČSR (2. směna). 0 deset let později ovšem směnování u nás takřka vymizelo.

Školstvím v socialistickém Československu se zabývá celá řada dalších (kvantitativně orientovaných) publikací (viz např. Lihocký, 1976; Novotná, 1985). Všechny uvedené prameny jsou běžně dostupné v knihovnách. Je zajímavé, že u některých knih je uvedena poznámka: pouze nebo výhradně „pro úřední potřebu" tehdejších úřradů či stranických orgánů, což naznačuje, že zřejmě šlo o neveřejné analýzy. Důležité ovšem je, že tyto dnes dobře dostupné zdroje mohou zčásti nahradit nedostupné archívní dokumenty.

K písemným publikovaným zdrojům patří rovněž odborná produkce $\mathrm{z}$ doby před rokem 1989. Není účelné zde vypisovat jednotlivé publikace, ale zmiňme pro ilustraci např. Třicet let československé jednotné školy (Kujal, 1979), některé Ciprovy práce apod. $V$ některých př́ípadech mohou posloužit jako zdroj k vývoji socialistické školy rovněž vysokoškolská skripta vydaná před rokem 1989 (viz např. Liškař, 1980).

Vedle odborných publikací jsou významným zdrojem rovněž dobové (odborné) pedagogické či „školské“ časopisy (např. Učitelské noviny, Socialistická škola, Pedagogika, Pedagogická orientace ${ }^{32}$, Komenský, Jednotná škola ${ }^{33}$ aj.), ale také dobové noviny. Do budoucna bude nutné zkoumat dobový tisk, například v letech 1968-1969 nebo kolem roku 1989, s cílem zjistit, jak bylo

31 V poválečném období (až do 60. let minulého století) byl v některých regionech nedostatek škol, proto musely některé děti chodit na tzv. druhou směnu (na odpoledne), v některých př́padech i na směnu třetí.

32 Ta však vycházela jen velmi krátce - více viz http://www.ped.muni.cz/pedor/profil/zhistorie.

33 Jednotná škola: časopis pre otázky pedagogickej teórie, praxe a psychologie. 
školství a školy prezentovány v médiích, jak se proměňovala témata, zda a jak byla prezentována témata $\mathrm{z}$ regionů apod.

Dalším důležitým okruhem historických pramenů jsou legislativní normy. Všechny důležité (nejenom školské) zákony jsou v současné době dostupné v elektronické podobě na webu ministerstva vnitra. ${ }^{34}$ Tento druh pramenů je navíc dobře dostupný $\mathrm{v}$ knihovnách. Legislativní normy patří $\mathrm{k}$ často využívaným zdrojům, viz např. zmiňované studie Vorlíčka (2004) či Walterové (2004).

Do jisté míry specifickým zdrojem písemných publikovaných pramenů je memoárová literatura. Př́kladem tohoto typu pramene mohou být knihy Co vy na to, pane Komenský? (Ludvíková, 2006) nebo Cesta do hlubin kantorovy duše (Hoznauer, 2004). Tento typ pramenů přináší sice subjektivní pohled na události, což je jejich slabá a současně i silná stránka. Svým charakterem mohou memoáry pomoci při studiu různých témat týkajících se života škol i učitelů - právě individuální zkušenosti mohou dodat další kamínek do mozaiky poznání minulosti, ale i inspirovat k novým výzkumným otázkám.

\section{Orální, vizuální a trojrozměrné historické prameny}

Nadpis této části naznačuje, že jsou zde sloučeny tři rozdílné typy pramenů, které ale mají jedno společné - nejsou u nás v historicko-pedagogickém výzkumu prakticky vůbec používány. Vysvětlení můžeme hledat v tradiční (a zcela pochopitelné) orientaci na práci s písemnými prameny. Dalším důvodem může být to, že např. vizuální prameny a nakonec i trojrozměrně prameny bývají používány spíše jako podpůrný pramen či doklad. Ten má ilustrovat zkoumaná témata či argumenty, nebo „pouze“ doplnit pramennou základnu tvořenou písemnými prameny. Nicméně tyto zdroje mohou sloužit jako základ pro historické zkoumání i hlavní zdroj poznání (McCulloch \& Richardson, 2000). Př́ḱlady vizuálních pramenů mohou být (architektonické) plány škol, různé druhy školních obrazů, ale především fotografie. ${ }^{35}$ Ty potenciálně obsahují celou řadu důležitých informací, protože mohou zobrazovat např. uspořádaní třídy a její vybavení, vybavení kabinetů, speciálních učeben či sportovišt', fotky žáků, učitelského sboru apod. Fotografie samotné

34 Viz http://aplikace.mvcr.cz/sbirka-zakonu

35 Některé tyto prameny mohou být uloženy v MZA či AMB, případně mohou být ještě uschovány ve školách. Lze předpokládat, že v archívech mohou být tyto prameny uloženy u témat jako inventarizace škol, generální opravy, pedagogické věci, pomůcky apod. 
mohou být mnohdy velmi důležitým pramenem, který vypovídá jak o škole, její architektuře, tak různých slavnostech či rituálech. Fotografie je možné ovšem využít jako podpůrný pramen, např. při orálně historickém rozhovoru. Respondent může popisovat nejenom fotku samotnou, ale i celý příběh jejího vzniku či zobrazenou událost v životě školy nebo v životě učitele.

K vizuálním zdrojům řadíme rovněž kreslené seriály či komiksy, ale také televizní pořady a film. Všechny uvedené prameny jsou málo využívané, navíc kreslené seriály u nás $\mathrm{v}$ době před sametovou revolucí nebyly příliš rozšířené. Nicméně televizní pořady (zejména zpravodajství, dokumenty) mohou být velmi zajímavým pramenem o tom, jak média před rokem 1989 informovala o škole a jaký vytvářela obraz o školství, učitelích, žácích či rodičích, at' už na národní či regionální úrovni.

$S$ fotografiemi souvisejí také trojrozměrné prameny, které bývají mnohdy na fotografiích zachyceny. Do skupiny těchto pramenů patří nejenom učební pomůcky, ale i samotné budovy ${ }^{36}$, veškerý školní nábytek či vybavení uvnitř i vně budovy školy (venkovní hřiště, dílny pro pracovní vyučování apod.). Při výzkumu je možné studovat vývoj a proměny učebních pomůcek (včetně učebnic). Zajímavé je rovněž studovat ergonometrii školního nábytku, rozmístění fyzických objektů ve třídě, ale také například organizaci a vybavení kabinetů učitelů nebo ředitelen (více viz např. Lawn \& Grosvenor, 2005). Zde se nabízí pro badatele zajímavá kombinace historických pramenů - fotografie a reálné dochované pomůcky či předměty. Trojrozměrné prameny k dějinám školství jsou uchovávány v muzeích. Např́klad Muzeum Komenského v Přerově připravilo stálou expozici historických tříd, kdy „nejnovější třída je z padesátých let minulého století. ${ }^{37}$ Národní pedagogické muzeum a knihovna J. A. Komenského v Praze má stálou expozici Vzdělanost a totalita (1938-1989). ${ }^{38}$ Muzea mohou být nejenom zdrojem celé řady důležitých historických pramenů k soudobému školství, ale také partnerem mezioborových výzkumných projektů, a to i na mezinárodní úrovni.

Posledním druhem historických pramenů jsou prameny orální povahy, které jsou tradičně označovány jako vzpomínky pamětníků. Po roce 1989 se u nás začíná rozvíjet metoda orální historie. Tu můžeme charakterizovat jako řadu

36 Při nedostatku budov se učilo v různých, mnohdy nevyhovujících, budovách či místnostech.

37 Více viz http://www.prerovmuzeum.cz/zamek-prerov/stale-expozice/skolni-trida-z-50-let20-stoleti.

38 Další informace na http://npmk.cz/node/50. 
propracovaných, avšak stále se vyvíjejících a dotvářejících se postupů, jejichž prostřednictvím se badatel... dobírá nových poznatků, a to na základě ústního sdělení osob, jež byly účastníky či svědky určité události, procesu nebo doby, které badatel zkoumá, nebo osob, jejichž individuální prožitky, postoje a názory mohou obohatit badatelovo poznání o nich samých, případně o zkoumaném problému obecně. (Vaněk \& Mücke, 2011, s. 9)

Vezmeme-li v úvahu fakt, že dostupnost písemných, mnohdy i vizuálních, pramenů může být velmi omezená, pak prameny získané prostřednictvím této metody mohou výrazně pomoci poznání soudobých dějin školství i pedagogiky. Konopásek (1999) píše, že studium životopisů a životních příběhů je mnohdy takřka jedinou možností, jak lze empirickým výzkumem poznat důležité charakteristiky bývalých komunistických společností. V totalitní společnosti nebyla celá řada dat či písemností oficiálně produkována, př́ípadně byla „upravována“ tak, aby sloužila politickým účelům nebo propagandě. Pro historicko-pedagogický výzkum může být velmi užitečné propojit výzkum založený na studiu písemných pramenů, vizuálních nebo trojrozměrných s orálně historickým výzkumem. Data získaná těmito přístupy se mohou doplňovat, nebo naopak pomohou vyvracet tradované mýty a nepřesnosti, př́ípadně otevírat nová výzkumná pole. V současnosti je možné využít vzpomínky pamětníků, které jsou dostupné na internetu v rámci projektu Pamět' národa ${ }^{39}$, nebo lze využít fyzické či digitální sbírky rozhovorů Centra orální historie $e^{40}$. Žádná z těchto sbírek není zaměřena primárně na školství, ale mnozí pamětníci vzpomínají na školu, na učitele, někteří pamětníci působili jako učitelé, takže je možné v těchto pramenech najít celou řadu důležitých informací.

\section{Závěr}

V naší studii jsme se snažili odpovědět na otázku, jaké zdroje má (nejenom) historik pedagogiky k dispozici, pokud se rozhodne zkoumat soudobé dějiny školství. Soustředili jsme se zejména na základní školy v bývalém Jihomoravském kraji v období normalizace. Toto zúžení vychází z našeho výzkumného projektu, ale je dáno rovněž omezeným prostorem jedné studie. Je ovšem zřejmé, že jde o tematiku velmi rozsáhlou a dané mantinely nás nutily k jistým kompromisům, co se týče šiřre i hloubky zpracování tématu. Tím

\footnotetext{
39 Viz http://www.pametnaroda.cz

40 Viz http://www.coh.usd.cas.cz/cs/katalog-a-sbirky-rozhovoru
} 
se dostáváme k omezením naší studie. Ta jsou dána několika faktory. V naší studii jsme nezachytili zdaleka archiválie uložené ve všech důležitých archivech, jako je např. Národní archiv, Archiv bezpečnostních složek, Archiv České televize nebo Národní filmový archiv. Podobně jsme neprozkoumali do detailu prameny dostupné ve všech pedagogických muzeích. Nemohli jsme $\mathrm{v}$ rámci jedné studie představit a vysvětlit teorii pramenů a popsat podrobněji jednotlivé skupiny zdrojů poznatků o minulosti. $V$ rámci př́́kladů jsme rezignovali na zahraniční př́klady. Nebyli jsme schopni postihnout všechnu metodologickou i historickou či historicko-pedagogickou literaturu, byt' se domníváme, že jsme čerpali ze všech základních tuzemských prací. Využili jsme rovněž některé zahraniční práce, $\mathrm{z}$ nichž některé jsou v ČR pouze obtížně dostupné nebo nejsou dostupné vůbec.

Zbývá tedy ona odpověd' na klíčovou otázku naší studie uvedenou výše. Jinými slovy řečeno: Jde tedy skutečně o terru inkognitu v oblasti zdrojů? Odpověd' není zcela jednoduchá a jednoznačná. Zdrojů k poznání dějin socialistického školství je poměrně velké množství, bohužel doposud známé a dostupné zdroje pokrývají pouze některé části života škol či aktérů školního života. To je dáno tím, že výzkum $\mathrm{v}$ této oblasti je $\mathrm{v}$ pedagogice teprve na začátku, ale významný problém představuje omezený přístup k pramenům. Zejména nezpracované archívní fondy reprezentují poměrně zásadní limitující faktor v rozvoji historicko-pedagogického bádání a podle vyjádření archivářủ může zpracování relevantních fondů trvat ještě hodně dlouhou dobu.

Dobrou zprávou jistě je, že existuje celá řada odborné literatury a výsledky výzkumů z jiných oblastí historiografie, které mohou přispět k poznání soudobých dějin školství jak na národní, tak na regionální úrovni. To znamená, že historicko-pedagogický výzkum může stavět na poznatcích jiných oborů. Výzvou je tedy nejenom bádání v rámci dějin pedagogiky a školství, ale také mezioborová spolupráce a (mezinárodní) výzkumné projekty, které mohou napomoci jak poznání minulosti, tak rozvinout metodologii historického výzkumu.

Zajímavou a užitečnou metodologickou inspiraci pro soudobé dějiny školství i pedagogiky (jako dějin vědeckého oboru) představuje metoda orální historie. $\mathrm{V}$ době, kdy stále nemáme $\mathrm{k}$ dispozici dostatek relevantních zdrojů poznání (zejména pramenů) a současně žijí pamětníci, je tato metoda velmi přínosná pro prohloubení poznání nedávné minulosti. $\mathrm{V}$ kombinaci s tradičními a osvědčenými postupy historického výzkumu tak vytváří 
obrovskou př́ležitost pro dějiny pedagogiky a školství i cestu k získání jedinečných pramenů.

Dějiny pedagogiky tak budou moci nabídnout př́buzným oborům nejenom výsledky svých bádání, ale i propojení metodologických poznatků z oblasti kvalitativního výzkumu v pedagogice s metodologií historického výzkumu. ${ }^{41}$

S jistou mírou optimismu tak můžeme říci, že v oblasti zdrojů poznání minulosti soudobých dějin stále existuje terra inkognita, ale existují dobré předpoklady její „rozlohu“ neustále zmenšovat.

\section{Literatura}

Aldrich, R. (2003). The three duties of the historian of education. History of Education: Journal of the History of Education Society, 32(2), 133-143.

Balík, S., \& Kubát, M. (2012). Teorie a praxe nedemokratických režimů. Praha: Dokořán.

Bernheim, E. (1931). Úvod do studia dějepisu. Praha: Jan Laichter.

Břeňová, V. (rok vydání neuveden). Soudobé dějiny. Obsah ročníků I-XV (2003-2008). Praha: Ústav pro soudobé dějiny. Dostupné z http://www.usd.cas.cz/UserFiles/File/Publikace/ biblio_1993_2008.pdf

Cach, J. (1991). Poznámky k vývoji politiky a institucí v oblasti školství - léta nadějí, krizí a zklamání 1945-1990. Pedagogika, 41(2), 135-144.

Cohen, L., Manion, L., \& Morrison, K. (2007). Research methods in education. New York: Routledge.

Čapka, F. (2006). Dějiny zemí Koruny české v datech. Dostupné z http://www.libri.cz/databaze/ dejiny/

Čermáková, M. (1991). Formování totalitního školství v poválečném Československu. Pedagogika, 41(3), 323-333.

Československé sčítání lidu 1970. (1970). Dostupné z http://notes.czso.cz/sldb2011/redakce. nsf/i/ceskoslovenske_scitani_lidu_1970

Československé sčítání lidu 1980. (1980). Dostupné z http://notes.czso.cz/sldb2011/redakce. nsf/i/ceskoslovenske_scitani_lidu_1980

Československé sčitání lidu 1991. (1991). Dostupné z http://notes.czso.cz/sldb2011/redakce. nsf/i/ceskoslovenske_scitani_lidu_1991

Československé školství v 5. pětiletce. (1976). Praha: Ústav školských inf. při min. školství ČSR. ${ }^{42}$ Čmejrková, S., Světlá, J., \& Daneš, F. (1999). Jak napsat odborný text. Praha: Leda.

Fasora, L., Hanuš, J., Malíř, J., \& Nečasová, D. (Eds.). (2011). Člověk na Moravě ve druhé polovině 20. století. Brno: CDK (Centrum pro studium demokracie a kultury).

41 Metodologii historicko-pedagogického výzkumu v oblasti výzkumu soudobých dějin školství se autoři věnují v samostatné studii. Zaměří se zejména na tzv. dějiny každodennosti, vizuální historii, orální historii, ale i studium životních príběhů (life history, life story) apod.

42 V knize je uvedeno: Pouze pro úřední potřebu. 
Gruner, P., \& Kluchert, G. (2001). Erziehungsabsichten und Sozialisationseffekte. Die Schule der SBZ und frühen DDR zwischen politischer Instrumentalisierung und institutioneller Eigenlogik. Zeitschrift für Pädagogik, 47(6), 859-868.

Hendl, J. (2005). Kvalitativní výzkum: základní metody a aplikace. Praha: Portál.

Historická statistická ročenka ČSSR. (1985). Praha: SNTL.

Hoznauer, M. (2004). Cesta do hlubin kantorovy duše. Praha: Dokořán.

Hroch, M. (1985). Úvod do studia dějepisu. Praha: Státní pedagogické nakladatelství.

Janiš ml., K. (2014). Jak tedy reflektovat socialistickou pedagogiku? Pedagogická orientace, 24(1), 128-132.

Jelínková, V., \& Smolka, R. (1989). Základní školství v ČSSR a některé trendy jeho vývoje od roku 1921. Praha: Ústav školských informací.

Jůva, V. (2009). Historická pedagogika. In J. Průcha (Ed.), Pedagogická encyklopedie (s. 672-676). Praha: Portál.

Kalinová, L. (1998). Sociální vývoj Československa 1969-1989. Praha: Ústav pro soudobé dějiny.

Kalinová, L. (2012). Konec nadějím a nová očekávání: k dějinám české společnosti 1969-1993. Praha: Academia.

Kerlinger, F. (1972). Základy výzkumu chování: pedagogický a psychologický výzkum. Praha: Academia.

Konopásek, Z. (1999). Otevřená minulost: autobiografická sociologie státního socialismu. Praha: Karolinum.

Köhler, H. (2001). Zensur, Leistung und Schulerfolg in den Schulen der DDR. Zeitschrift für Pädagogik, 47(6), 847-857.

Kučerová, S. (2012). Proměny územní struktury základního školství v Česku. Praha: Česká geografická společnost.

Kujal, B. (1979). Třicet let československéjednotnéškoly. Praha: Státní pedagogické nakladatelství.

Lawn, M., \& Grosvenor, I. (2005). Materialities of schooling: Design, technology, objects, routines. Oxford: Symposium Books.

Le Goff, J. (1983). Later history. Past and Present, 100(1), 14-28.

Lihocký, J. (1976). Štatistická ročenka školstva Československej socialistickej republiky 19681974: pre vnútornú potrebu. Bratislava: Ústav školských informací.

Liškař, Č. (1980). Socialistické školství: určeno pro posl. filozof. fak. Univ. J. E. Purkyně. Praha: SPN.

Ludvíková, M. (2006). Co vy na to, pane Komenský? Praha: Triton.

Maňák, J. (2013). Pedagogika a pedagogové v období vlády komunismu. Pedagogická orientace, 23(3), 386-391.

Mareš, J. (2010). O vstupování na tenký led. Pedagogika, 60(2), 99-103.

Mareš, J. (2013). Přehledové studie: jejich typologie, funkce a způsob vytváření. Pedagogická orientace, 23(4), 427-454.

Matějů, P., \& Večerník, J. (1998). Zpráva o vývoji české společnosti 1989-1998. Praha: Academia. Mayer, F. (2009). Češi a jejich komunismus: pamět’ a politická identita. Praha: Argo.

McCulloch, G., \& Richardson, W. (2000). Historical research in educational settings. Buckingham: Open University Press.

Medick, H. (2001). Quo vadis historische Anthropologie? Geschichtsforschung zwischen historischer Kulturwissenschaft und Mikro-Historie. Historische Antropologie, 9(1), 78-92. 
Moree, D. (2013). Učitelé na vlnách transformace: kultura školy před rokem 1989 a po něm. Praha: Karolinum.

Nejedlá, D. (2000). Historická tematika na stránkách Pedagogiky v uplynulém padesátiletí. Pedagogika, 50(4), 406-421.

Novotná, L. (1985). Sít’ základních škol v ČSR ve školním roce 1984-85. Praha: Ústav školských informací při ministerstvu školství ČSR.

Otáhal, M., Bolomský, K., \& Nosková, A. (1993). Svědectví o duchovním útlaku 1969-1970: Dokumenty: „Normalizace“ v kultuře, umění, vědě, školství a masových sdělovacích prostredcích. Praha: Maxdorf.

Otáhal, M. (1994). Opozice, moc, společnost 1969-1989: Příspěvek k dějinám „normalizace“. Praha: Maxdorf.

Otáhal, M. (2002). Normalizace 1969-1989: příspěvek ke stavu bádání. Praha: Ústav pro soudobé dějiny AV ČR.

Otáhal, M. (2011). Opoziční proudy v české společnosti 1969-1989. Praha: Ústav pro soudobé dějiny AV ČR.

Pehnke, A. (2008). Widerständige sächsische Schulreformer im Visier stalinischer Politik (1945-1959). Frankfurt am Main: Peter Lang.

Průcha, J. (2009a). Historický vývoj českého školství II (1948-1989). In J. Průcha (Ed.), Pedagogická encyklopedie (s. 45-49). Praha: Portál.

Průcha, J. (Ed.). (2009b). Pedagogická encyklopedie. Praha: Portál.

Průcha, J. (2011). Vstoupit či nevstoupit na tenký led analýzy socialistické pedagogiky? Pedagogika, 61(2), s. 187-190.

Průcha, J., Walterová, E., \& Mareš, J. (2013). Pedagogický slovník. Praha: Portál.

Průcha, V. (2009). Hospodářské a sociální dějiny Československa 1918-1992. (2. sv.). Brno: Doplněk.

Pešek, J. (2013). Napříč kontinentem soudobých dějin: evropská historiografie po konci studené války. Praha: Argo.

Pullmann, M. (2011). Konec experimentu: přestavba a pád komunismu v Československu. Praha: Scriptorium.

Rýdl, K. (2006). Historický vývoj českého vzdělávání do roku 1989. In J. Kalous \& A. Veselý (Eds.), Vzdělávací politika České republiky v globálním kontextu (s. 7-22). Praha: Karolinum.

Skládaný, M. (2009). Metody edukační historiografie. In Š. Švec (Ed.), Metodologie věd o výchově: kvantitativně-scientické a kvalitativně-humanitní př́stupy v edukačním výzkumu (s. 234-241). Brno: Paido.

Slovníková příručka k československým dějinám 1948-1989. (2006). Dostupné z www.usd.cas.cz/ UserFiles/File/Publikace/Prirucka48_89.pdf

Statistická ročenka města Brna. (1970). Brno: Český statistický úřad.

Svatoš, T. (2009). Dějiny vzdělanosti. In J. Průcha (Eds.), Pedagogická encyklopedie (s. 677-680). Praha: Portál.

Svatoš, T. (2010). Aby pedagogika byla vědou provázenou historickou reflexí. Pedagogika, 60(1), $1-3$.

Tenorth, H. E., Kudella, S., \& Paetz, A. (1996). Politisierung im Schulalltag der DDR. Durchsetzung und Scheitern einer Erziehungsambition. Weinheim: Dt. Studien-Verlag.

Travers, R. (1969). Úvod do pedagogického výzkumu. Praha: Státní pedagogické nakladatelství. 
Třeštík, D. (1997). Počátky Přemyslovců: vstup Čechů do dějin (530-935). Praha: Nakladatelství Lidové noviny.

Urbášek, P. (2008). Vysokoškolský vzdělávací systém v letech tzv. normalizace. Olomouc: Univerzita Palackého v Olomouci.

Úvod do studia dějepisu. (2014). Brno: Masarykova univerzita. Dostupné z http://digilib.phil. muni.cz/handle/11222.digilib/130405

Václavík, V. (1997). Cesta ke svobodné škole: kapitoly ze srovnávací pedagogiky. Hradec Králové: Líp.

Vaculík, J., \& Čapka, F. (2011). Úvod do studia dějepisu a historický proseminář. Brno: Masarykova univerzita.

Vaněk, M. (2004). Orální historie ve výzkumu soudobých dějin. Praha: Ústav pro soudobé dějiny AV ČR.

Vaněk, M., Mücke, P., \& Pelikánová, H. (2007). Naslouchat hlasům paměti: teoretické a praktické aspekty orální historie. Praha: Ústav pro soudobé dějiny AV ČR.

Vaněk, M., \& Mücke, P. (2011). Třetí strana trojúhelníku: teorie a praxe orální historie. Praha: Fakulta humanitních studií UK v Praze.

Vaněk, M. (2013). Around the globe: Rethinking oral history with its protagonists. Prague: Karolinum.

Vaněk, M., \& Krátká, L. (2014). Příběhy (ne)obyčejných profesí: česká společnost v období tzv. normalizace a transformace. Praha: Karolinum.

Vorlíček, Ch. (2004). České školství 1945-2000. In E. Walterová (Ed.), Česká pedagogika: proměny a výzvy: sborník $k$ životnímu jubileu profesora Jiřího Kotáska (s. 119-176). Praha: Univerzita Karlova v Praze - Pedagogická fakulta.

Vykoupil, L. (2000). Slovník českých dějin. Brno: J. Zirkus.

Walterová, E. (2004). Úloha školy v rozvoji vzdělanosti (1. sv.). Brno: Paido.

Weller, T. (2013). History in the digital age. London: Routledge.

Zákon o územním členění státu č. 36/1960 Sb. (1960). Dostupné z http://www.zakonyprolidi.cz/ cs/1960-36\#p1.

Zákon o archivnictví a spisové službě a o změně některých zákonů, č. 499/2004 Sb. Dostupné z http://aplikace.mvcr.cz/sbirka-zakonu/SearchResult.aspx?q=499/2004\&typeLaw= zakon\&what=Cislo_zakona_smlouvy

Zounek, J., \& Jedlička, P. (2005). K vývoji a proměnám časopisu Pedagogická orientace v letech 1991-2004. Pedagogická orientace, 15(4), 68-78.

Zounek, J., \& Vichrová, M. (2008). Der Wissenschaftler und Pädagoge in den totalitären Regimen des 20. Jahrhunderts in der Tschechoslowakei. In A. Pehnke (Ed.), Widerständige sächsische Schulreformer im Visier stalinischer Politik (1945-1959) (s. 216-228). Frankfurt am Main: Peter Lang.

Zounek, J. (2011). Učitel - Příběh normálního života v nenormální době. In L. Fasora, J. Hanuš, J. Maliŕr, \& D. Nečasová (Eds.), Člověk na Moravě ve druhé polovině 20. století. (s. 241-252). Brno: Centrum pro studium demokracie a kultury.

Zounek, J., \& Šimáně, M. (2014). Úvod do studia dějin pedagogiky a školství: kapitoly z metodologie historicko-pedagogického výzkumu. Brno: Masarykova univerzita. 


\title{
Autoři
}

Doc. Mgr. Jiří Zounek, Ph.D., Masarykova univerzita, Filozofická fakulta, Ústav pedagogických věd, Arna Nováka 1, 60200 Brno, e-mail: zounek@phil.muni.cz

Mgr. Michal Šimáně, Masarykova univerzita, Filozofická fakulta, Ústav pedagogických věd, Arna Nováka 1, 60200 Brno, e-mail: simane@phil.muni.cz

Doc. PhDr. Dana Knotová, Ph.D., Masarykova univerzita, Filozofická fakulta, Ústav pedagogických věd, Arna Nováka 1,602 00 Brno, e-mail: knotova@phil.muni.cz

\section{The history of socialist education: terra incognita of historical-pedagogical research? To the issue of the sources of the past}

\begin{abstract}
This paper focuses on revising the sources of the past for studying the history of socialist education in Czechoslovakia. The authors asked themselves what sources are available for historian of education, if he decides to examine contemporary history of education. This question is important especially in the context of primary education in the former South Moravian Region in 1969-1989. In the first part of the text, the authors present their scheme of partition of sources. In the following sections, the various types of sources (historical sources, professional publications, auxiliary sources and literature) are discussed in detail and complemented by concrete examples. The paper draws attention to the fact that there is relatively large amount of sources for getting knowledge about the history of socialist education. Unfortunately, sources which are available and acknowledged up until the present cover only some parts of school life and school life actors. On the other hand, there is a lot of scientific literature and research results from other areas of historiography, which may contribute to the understanding of contemporary history of education at both the national and regional level. This means that the historical-educational research can build on the knowledge of other disciplines.
\end{abstract}

Keywords: socialist education, historical sources, professional publications, auxiliary sources and literature, archival funds

Jirsa, J. (Ed.). (2015). Idea university. Praha: Academia.

Současná rozprava o vysokém školství postrádá hlubší zakotvení v debatě, která se o podstatě a funkci moderního univerzitního vzdělávání vede nejméně od 19. století. Sborník přináší jednak historické texty o ideji univerzity a konceptu tzv. liberálního vzdělávání (vzdělávání svobodných osob, popř. vzdělání vedoucí ke svobodě) a jednak texty, které reagují na krizi univerzity na počátku 21 . století. 